Jurnal Tanah dan Sumberdaya Lahan Vol 7 No 2 : 181-194, 2020

e-ISSN:2549-9793, doi: 10.21776/ub.jts1.2020.007.2.1

\title{
KARAKTERISASI POTENSI PENGEMBANGAN KAWASAN CABAI DAN BAWANG MERAH DI KABUPATEN BIMA, NUSA TENGGARA BARAT
}

\section{Characterization of Chili and Shallot Development Region in Bima District, West Nusa Tenggara}

\author{
Popi Rejekiningrum*, Sofyan Ritung \\ Balai Besar Penelitian dan Pengembangan Sumberdaya Lahan Pertanian (BBSDLP) \\ Jl. Tentara Pelajar No. 12, Bogor, Jawa Barat \\ *Penulis korespondensi: popirejeki@gmail.com
}

\begin{abstract}
The productivity of chili and shallot in Indonesia is still low, but Indonesia has great opportunities to increase chili and shallot productivity either through intensification and extensification. The objectives of the research were (1) to compile and develop land resources data, including climate and hydrology information in chili and shallot regions, (2) to compose maps of chili and shallot development regions. (3) to create recommendations on land, climate, and water management for chili and shallot development regions. Mapping of development of chili and shallot areas scale 1: 50,000 was carried out by desk work and field verification. Recommendation of the development of chili and shallot commodity areas are arranged based on land suitability class by considering existing land use, and commodity centres on APL land (Other Use Areas). The results of the analysis showed that Bima District has an area of 8,696 ha of shallot area and potential for extensification development of 60,363 ha consisting of high development potential (P.1) of 4,675 ha and moderate (P.2) of 55,688 ha. P.1 is moderately suitable with the dominant inhibiting factors of nitrogen and phosphorus. P.2 is marginal according to the dominant limiting factor of low rainfall. Chili does not have suitable area because the existing land is scattered in a narrow area, but has a development potential of 46,159 ha consisting of high development potential area (P.1)of 3,280 ha, and moderate area (P.2) of 42,879 ha.
\end{abstract}

Keywords: chili, development region, dry land, shallot

\section{Pendahuluan}

Indonesia adalah negara agraris yang memiliki sumberdaya alam beragam, sehingga banyak pilihan komoditas yang dapat dikembangkan. Dalam kenyataannya pola pengembangan komoditas terpencar dan dalam skala kecil. Di sisi lain, pengusahaan komoditas dilakukan secara parsial dan mono komoditas, menjadikan usaha tani tidak efisien, pembinaan sulit dilakukan dan pemanfaatan sumberdaya kurang optimal, sehingga dampaknya terhadap kesejahteraan petani kurang terlihat. Oleh sebab itu, tahun 2012, Kementerian Pertanian melakukan reorientasi manajemen pembangunan pertanian seiring dengan terbitnya Permentan Nomor 50 Tahun 2012 sebagaimana direvisi menjadi Permentan Nomor 56 Tahun 2016 tentang Pedoman Pengembangan Kawasan Pertanian. Pendekatan kawasan pertanian dimaksudkan agar kegiatan pembangunan pertanian dilakukan secara fokus lokasi, fokus komoditas, skala ekonomi, holistik, dan terintegrasi. Dengan demikian pemanfaatan sumberdaya lebih optimal, penggunaan anggaran lebih efisien, dan diharapkan berdampak lebih signifikan terhadap peningkatan produksi, produktivitas dan daya saing komoditas yang pada gilirannya meningkatkan kesejahteraan petani.

Untuk mewujudkan kebijakan pembangunan pertanian melalui pendekatan 


\section{Jurnal Tanah dan Sumberdaya Lahan Vol 7 No 2 : 181-194, 2020 \\ e-ISSN:2549-9793, doi: 10.21776/ub.jts1.2020.007.2.1}

kawasan, diperlukan data dan informasi sumberdaya lahan berbasis spasial pada skala yang lebih detail (1:50.000) guna menyusun rekomendasi dan arahan penataan sistem pertanian yang operasional di lapangan. Pada skala tersebut, data sumberdaya lahan memberikan informasi potensi, kendala biofisik lahan, luas dan sebaran di suatu wilayah untuk pengembangan komoditas pertanian, termasuk komoditas cabai dan bawang merah. Rekomendasi pengelolaan lahan diperlukan untuk mendukung pengembangan komoditas di setiap Kawasan (Kementan, 2017).

Cabai dan bawang merah merupakan salah satu komoditas hortikultura strategis dalam perekonomian Nasional. Tingkat konsumsi cabai dan bawang merah yang sangat tinggi harus diimbangi dengan ketersediaan, sehingga peningkatan produksi cabai dan bawang merah sangat diperlukan. Peningkatan produksi cabai dan bawang merah diharapkan dapat meredam volatilitas harga sehingga mampu mengendalikan inflasi terutama komoditas bahan makanan. Tahun 2016 data BPS menunjukkan, Indonesia mampu memproduksi cabai besar sebesar 1.045.587 ton, cabai rawit sebesar 915.988 ton dan bawang merah sebesar 1.446 .860 ton. Rata-rata produktivitas cabai besar sebesar 8,47 $\mathrm{t} \mathrm{ha}^{-1}$, cabai rawit 6,7 $\mathrm{t} \mathrm{ha}^{-1}$, dan bawang merah sebesar 9,67 t ha ${ }^{-1}$. Tingkat produktivitas cabai dan bawang merah Indonesia ini masih lebih rendah dibandingkan dengan potensi produktivitas yang dapat mencapai 12-20 tha $\mathrm{a}^{-1}$ untuk cabai dan di atas 20 $\mathrm{t} \mathrm{ha}^{-1}$ untuk bawang merah (Kementan, 2017).

Rendahnya produktivitas cabai merah dan bawang merah menjadi peluang bagi Indonesia untuk menigkatkan produktivitas, baik melalui pertanaman cabai dan bawang merah yang ada (intensifikasi lahan eksisting) maupun perluasan areal tanam (ekstensifikasi). Pengembangan kawasan diharapkan dapat memberikan solusi terhadap permasalahan cabai dan bawang merah di Indonesia melalui pengembangan sistem agribisnis mulai dari hulu sampai hilir.

Tujuan kegiatan penyusunan Atlas Peta Pengembangan Kawasan Cabai dan Bawang Merah Skala 1:50.000 di Kabupaten Bima adalah untuk (1) menyusun dan mengembangkan data dan informasi sumberdaya lahan di kawasan cabai dan bawang merah, (2) menyusun peta pengembangan kawasan cabai dan bawang merah, dan (3) menyusun rekomendasi pengelolaan lahan di kawasan pengembangan cabai dan bawang merah

\section{Bahan dan Metode}

Kegiatan penyusunan Peta Pengembangan Kawasan Cabai dan Bawang Merah Skala 1:50.000 dilaksanakan secara desk work dan verifikasi lapang. Arahan pengembangan kawasan komoditas cabai dan bawang merah disusun berdasarkan kelas kesesuaian lahan dengan mempertimbangkan penggunaan lahan eksisting, dan sentra kedua komoditas tersebut pada lahan APL (Areal Penggunaan Lain), sedangkan pada kawasan hutan tidak direkomendasikan. Arahan pengembangan kawasan komoditas cabai dan bawang merah disajikan dalam bentuk tabular dan spasial/peta berbasis kabupaten/kota.

\section{Bahan dan peralatan}

Bahan yang digunakan adalah: (i) Peta Tanah Semidetail skala 1:50.000 Kabupaten Bima versi update (BBSDLP, 2016), (ii) Peta Rupabumi Indonesia (RBI) skala 1:50.000, (iii) Peta Batas Administrasi kabupaten/kota (BPS, 2016), (iv) Peta Status Kawasan Hutan (KLHK, 2013), (v) Peta Lahan Sawah (Kementan, 2013), (vi) Peta Penggunaan Lahan (BPN, 2012), (vii) Peta Penguasaan Lahan (Kementerian ATR, 2015), (viii) data karakteristik lahan (LC) Kabupaten Bima, (ix) Kriteria Kesesuaian Lahan untuk Komoditas Pertanian (Ritung et al., 2011), dan (x) Atlas Sumberdaya Iklim Pertanian Indonesia skala 1:1.000.000 (Puslitbangtanak, 2003).

\section{Metode}

Kegiatan penyusunan Peta Kawasan Pengembangan Cabai dan Bawang Merah skala 1:50.000 dibagi menjadi 7 tahapan kegiatan, yaitu: (1) Persiapan, (2) Penyusunan satuan evaluasi lahan, (3) evaluasi lahan dan penyusunan peta kesesuaian lahan, (4) Penyusunan peta kawasan cabai dan bawang merah (draft), (5) Verifikasi lapangan, (6) Penyusunan peta kawasan cabai dan bawang merah (final), dan (7) Pelaporan. Diagram alir penyusunan peta kawasan disajikan pada Gambar 1. 


\section{Jurnal Tanah dan Sumberdaya Lahan Vol 7 No 2 : 181-194, 2020 \\ e-ISSN:2549-9793, doi: 10.21776/ub.jts1.2020.007.2.1}

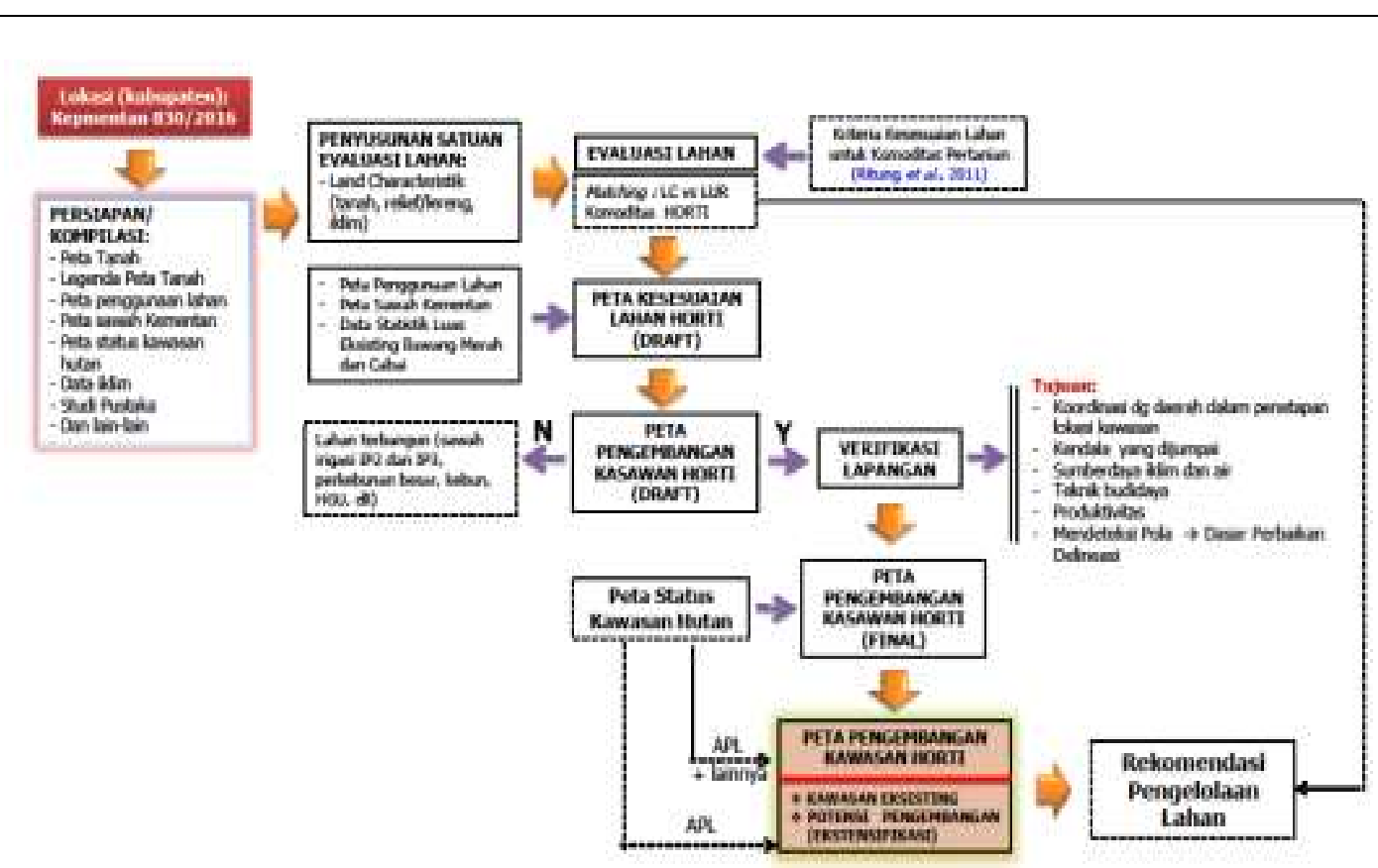

Gambar 1. Diagram alir prosedur penyusunan atlas peta pengembangan kawasan cabai dan bawang merah skala 1:50.000.

\section{Persiapan}

Tahap persiapan meliputi kompilasi bahanbahan yang diperlukan dalam penyusunan peta pengembangan kawasan cabai dan bawang merah, seperti Peta Tanah, Peta RBI (Bakosurtanal, 2017), Peta Batas Administrasi kabupaten/kota dari BPS, Peta Status Kawasan Hutan dari KLHK, Peta Lahan Sawah Kementan, Peta Penggunaan Lahan dari BPN, Peta Penguasaan lahan dari Kementerian ATR, dan Kriteria Kesesuaian Lahan untuk cabai dan bawang merah. Selain kompilasi bahan-bahan yang diperlukan, pada tahapan ini juga dilakukan studi pustaka mempelajari kondisi wilayah (kabupaten/kota), antara lain kondisi iklim, kondisi pertanian cabai dan bawang merah, data statistik luas tanam eksisting cabai dan bawang merah, produktivitas dan lain-lain.

Penyusunan satuan evaluasi lahan

Satuan evaluasi lahan adalah unit lahan yang digunakan dalam penilaian kesesuaian lahan, terdiri atas karakteristik lahan, berupa karakteristik tanah, iklim dan topografi. Nomor satuan evaluasi lahan mengacu pada nomor pada satuan peta tanah. Data karakteristik tanah meliputi: drainase, tekstur, bahan kasar (\%), kedalaman tanah $(\mathrm{cm})$, ketebalan $(\mathrm{cm})$ dan tingkat kematangan gambut, KTK tanah, KB (\%), $\mathrm{pH} \mathrm{H} \mathrm{H}_{2} \mathrm{O}, \mathrm{C}$ organik (\%), $\mathrm{N}$ total (\%), $\mathrm{P}_{2} \mathrm{O}_{5}$ dan $\mathrm{K}_{2} \mathrm{O}$ ekstrak $\mathrm{HCl} 25 \%$ (mg $100 \mathrm{~g}^{-1}$ ), salinitas (ds $\left.\mathrm{m}^{-1}\right)$, kedalaman sulfidik $(\mathrm{cm})$, tinggi $(\mathrm{cm})$ dan lama genangan, singkapan dan batuan dipermukaan (\%); karakteristik iklim, seperti: temperatur udara, curah hujan tahunan (mm), bulan basah dan bulan kering (Schmidt dan Fergusson, 1951; Oldeman et al., 1978), kelembaban udara (\%); dan karakteristik lingkungan, seperti: elevasi (m dpl), dan lereng $(\%)$.

Evaluasi lahan dan penyusunan peta kesesuaian lahan

Evaluasi lahan adalah proses penilaian keragaan (performance) lahan jika digunakan untuk penggunaan tertentu (FAO, 1976). Evaluasi lahan dilakukan terhadap cabai dan bawang merah dengan cara membandingkan (matching) antara kualitas/karakteristik lahan (land quality/characteristics) dengan persyaratan penggunaan lahan (land use requirements). Evaluasi lahan menghasilkan kelas-kelas kesesuaian lahan dan faktor pembatas yang digunakan sebagai dasar penyusunan rekomendasi pengelolaan lahan. Kriteria Penilaian Kesesuaian Lahan untuk Komoditas Pertanian mengacu pada 


\section{Jurnal Tanah dan Sumberdaya Lahan Vol 7 No 2 : 181-194, 2020 \\ e-ISSN:2549-9793, doi: 10.21776/ub.jts1.2020.007.2.1}

Ritung et al. (2011). Evaluasi lahan untuk penyusunan peta kesesuaian lahan komoditas cabai dan bawang merah skala 1:50.000 dilakukan sampai tingkat sub-kelas. Pada tingkat ini (sub kelas), setiap kelas kesesuaian dibedakan berdasarkan faktor pembatas terberat mengikuti hukum minimum Liebig (Minimum Liebig Law). Menurut FAO (1976), hierarki klasifikasi kesesuaian lahan adalah sebagai berikut: OrdoKelas-Subkelas-Unit. Ordo menggambarkan tingkat kesesuaian lahan secara umum, dibedakan atas lahan sesuai (S), dan lahan tidak sesuai $(\mathrm{N})$; Kelas adalah tingkat kesesuaian lahan dalam Ordo, dibedakan atas lahan sangat sesuai (S1), lahan cukup sesuai (S2), dan lahan sesuai marginal (S3). Lahan tidak sesuai (N) tidak dibedakan kedalam kelas-kelas. Tabel 1 menyajikan kelas dan kondisi faktor pembatas di masing-masing kelas kesesuaian lahan. Tabel 2 menyajikan kualitas dan karakteristik lahan yang digunakan dalam penilaian kesesuaian lahan. Berdasarkan tabel tersebut terdapat 13 kualitas lahan dan 25 karakteristik lahan yang digunakan dalam penilaian kelas kesesuaian lahan. Hasil tahapan ini adalah draft peta kesesuaian lahan yang menyajikan kelas kesesuaian lahan secara fisik. Selanjutnya draft peta kesesuaian lahan dikoreksi dengan Peta Sawah Kementan (2013) dan Peta Penggunaan Lahan dari BPN (2012) menghasilkan draft peta kesesuaian lahan aktual yang akan digunakan untuk penyusunan peta pengembangan kawasan pertanian. Semua proses pengolahan data/peta menggunakan perangkat lunak GIS (Geographic Information System) seperti ArcGIS, ArcView.

Tabel 1. Pembagian kelas kesesuaian lahan.

\begin{tabular}{ll}
\hline Kelas kesesuaian lahan & Faktor pembatas \\
\hline Sangat Sesuai (S1) & Lahan tidak mempunyai faktor pembatas yang berarti atau mempunyai \\
& faktor pembatas minor yang tidak mereduksi produktivitas lahan secara \\
& nyata. \\
& Lahan mempunyai faktor pembatas yang berpengaruh terhadap \\
Cukup Sesuai (S2) & produktivitas, memerlukan input, namun masih dapat diatasi oleh \\
& petani. \\
& Lahan mempunyai faktor pembatas berat yang berpengaruh terhadap \\
Sesuai Marginal (S3) & produktivitasnya, memerlukan input yang lebih banyak dari kelas S2. \\
& Untuk mengatasi faktor pembatas pada kelas S3 memerlukan modal \\
& yang tinggi, sehingga perlu adanya bantuan atau campur tangan \\
& (intervensi) pemerintah atau swasta. \\
& Lahan yang tidak sesuai (N) karena mempunyai faktor pembatas yang \\
Tidak sesuai $(\mathrm{N})$ & sangat berat dan/atau sulit diatasi. \\
\hline
\end{tabular}

Sumber: FAO (1976); Djaenuddin et al. (2003).

\section{Penyusunan peta pengembangan kawasan}

Penyusunan peta pengembangan kawasan cabai dan bawang merah didasarkan pada hasil penilaian kesesuaian lahannya yang tergolong sangat sesuai, cukup sesuai dan sesuai marjinal yang dapat diperbaiki pembatasnya. Lahan yang sesuai tersebut berada pada lahan APL (area penggunaan lain), bukan lahan kawasan hutan, berupa lahan tegalan atau lahan sawah tadah hujan dengan IP-100 dan merupakan sentra dari kedua komoditas tersebut. Lahan yang mempunyai potensi untuk cabai dan bawang merah namun bukan sebagai sentra akan diarahkan untuk potensi perluasan atau potensi pengembangan ekstensifikasi. Areal sentra cabai dan bawang merah yang diarahkan sebagai pengembangan kawasan mempunyai luasan minimal 50 ha dan terkonektivitas sesuai dengan ketentuan pembentukan kawasan cabai dan bawang merah. Kawasan pengembangan dibedakan berdasarkan peningkatan produktivitas yang mungkin dicapai dari kondisi eksisting ke produktivitas optimal masingmasing komoditas. Dibedakan 3 kelas peningkatan produktivitas seperti disajikan pada Tabel 3 untuk bawang merah, cabai merah besar, dan cabai rawit. 


\section{Jurnal Tanah dan Sumberdaya Lahan Vol 7 No 2 : 181-194, 2020}

e-ISSN:2549-9793, doi: 10.21776/ub.jts1.2020.007.2.1

Tabel 2. Kualitas dan karakteristik lahan yang digunakan dalam penilaian kesesuaian lahan.

\begin{tabular}{|c|c|c|c|}
\hline No. & Kualitas Lahan & Karakteristik Lahan & Sumber data \\
\hline 1. & Temperatur (tc) & $\begin{array}{l}\text { Temperatur rata-rata tahunan } \\
\left({ }^{\circ} \mathrm{C}\right)\end{array}$ & $\begin{array}{l}\text { Stasiun iklim setempat/ } \\
\text { data sekunder (BMKG) }\end{array}$ \\
\hline 2. & Ketersediaan air (wa) & $\begin{array}{l}\text { Curah hujan (mm) } \\
\text { Kelembaban udara }(\%)\end{array}$ & $\begin{array}{l}\text { Stasiun iklim setempat/ } \\
\text { data sekunder (BMKG) }\end{array}$ \\
\hline 3. & Keters. oksigen (oa) & Drainase & Pengamatan lapangan \\
\hline 4. & Media perakaran (rc) & $\begin{array}{l}\text { Tekstur, Bahan kasar }(\%) \\
\text { Kedalaman efektif }(\mathrm{cm}) \text {, } \\
\text { Kematangan gambut, dan } \\
\text { Ketebalan gambut }(\mathrm{cm})\end{array}$ & Pengamatan lapangan \\
\hline 5. & Retensi hara (nr) & $\begin{array}{l}\left.\text { KTK tanah (me } 100 \mathrm{~g}^{-1}\right) \\
\text { Kejenuhan Basa }(\%), \mathrm{pH} \text { tanah, } \\
\text { dan C organik }(\%)\end{array}$ & $\begin{array}{l}\text { Analisis lab. (khusus } \mathrm{pH} \\
\text { juga dilakukan pengamatan } \\
\text { di lapangan) }\end{array}$ \\
\hline 6. & Hara tersedia (na) & $\begin{array}{l}\mathrm{N} \text { total }(\%), \mathrm{P}_{2} \mathrm{O}_{5}\left(\mathrm{mg} 100 \mathrm{~g}^{-1}\right) \\
\mathrm{K}_{2} \mathrm{O}\left(\mathrm{mg} 100 \mathrm{~g}^{-1}\right)\end{array}$ & Analisis laboratorium \\
\hline 7. & Toksisitas (xc) & Salinitas $\left(\mathrm{mmhos} \mathrm{cm}^{-1}\right)$ & Analisis laboratorium \\
\hline 8. & Sodisitas (xn) & Alkalinitas (\%) & Perhitungan \\
\hline 9. & Bahaya sulfidik (xs) & Kedalaman sulfidik $(\mathrm{cm})$ & Pengamatan lapangan \\
\hline 10. & Tingkat bahaya erosi (eh) & $\begin{array}{l}\text { Lereng }(\%) \\
\text { Bahaya erosi }\left(\mathrm{cm} \mathrm{tahun}^{-1}\right)\end{array}$ & $\begin{array}{l}\text { Pengamatan lapangan } \\
\text { Perhitungan }\end{array}$ \\
\hline 11. & Bahaya longsor & Lereng \%), dan Bahaya longsor & Pengamatan lapangan \\
\hline 12. & $\begin{array}{l}\text { Bahaya banjir/genangan } \\
\text { (fh) }\end{array}$ & Genangan ( $\mathrm{cm}$ bulan $\left.{ }^{-1}\right)$ & Pengamatan lapangan \\
\hline 13. & Penyiapan lahan (lp) & $\begin{array}{l}\text { Batuan di permukaan }(\%) \\
\text { Singkapan batuan }(\%)\end{array}$ & Pengamatan lapangan \\
\hline
\end{tabular}

Sumber: FAO (1976); Djaenudin et al. (2003), Ritung et al. (2011).

Tabel 3. Kelas peningkatan produktivitas bawang merah dan cabai merah besar.

\begin{tabular}{|c|c|c|c|c|}
\hline \multirow{3}{*}{$\begin{array}{l}\text { Peningkatan } \\
\text { Produktivitas }\end{array}$} & \multicolumn{2}{|c|}{ Bawang Merah dan Cabai Merah Besar } & \multicolumn{2}{|c|}{ Cabai Rawit } \\
\hline & $\begin{array}{c}\text { Produktivitas } \\
\text { Optimal }\end{array}$ & Yield gap & $\begin{array}{c}\text { Produktivitas } \\
\text { Optimal }\end{array}$ & Yield gap \\
\hline & \multicolumn{2}{|c|}{ t ha $^{-1}$ musim $^{-1}$} & \multicolumn{2}{|c|}{ t ha $^{-1}$ musim $^{-1}$} \\
\hline Rendah & 20 & $<3,8$ & 15 & $<2,9$ \\
\hline Sedang & 20 & $3,8-7,8$ & 15 & $2,9-5,9$ \\
\hline Tinggi & 20 & $>7,8$ & 15 & $>5,9$ \\
\hline
\end{tabular}

Lahan potensial untuk pengembangan ekstensifikasi cabai dan bawang merah dibedakan atas 2 kelas, yakni potensi pengembangan tinggi (P1) jika kelas kesesuaian lahannya tergolong sangat sesuai (S1), dan potensi pengembangan sedang (P2) jika kelas kesesuaian lahannya tergolong cukup sesuai (S2) dan sesuai marjinal (S3) apabila faktor pembatasnya relatif mudah diperbaiki, misalnya retensi hara, ketersediaan hara dan air.

\section{Verifikasi lapangan}

Verifikasi lapangan dilakukan terhadap peta pengembangan kawasan cabai dan bawang merah dan sentra komoditas cabai dan bawang merah serta lahan potensial untuk pengembangannya. Tujuan dari verifikasi lapangan adalah untuk mengetahui tingkat akurasi peta pengembangan kawasan cabai dan bawang merah yang disusun berdasarkan peta kesesuaian lahan dan peta-peta tematik lainnya. 


\section{Jurnal Tanah dan Sumberdaya Lahan Vol 7 No 2 : 181-194, 2020 \\ e-ISSN:2549-9793, doi: 10.21776/ub.jts1.2020.007.2.1}

Verifikasi akurasi peta pengembangan kawasan dan potensi pengembangan cabai dan bawang merah di lapangan dilakukan antara lain terhadap: (i) sentra komoditas cabai dan bawang merah, (ii) keragaan (performance) tanaman di lapangan, (iii) penggunaan lahan, (iv) pengelolaan lahan, termasuk preferensi masyarakat terhadap komoditas cabai dan bawang merah.

\section{Hasil dan Pembahasan}

\section{Kondisi sumberdaya lahan}

\section{Lokasi dan perbubungan}

Kabupaten Bima adalah salah satu kabupaten di Provinsi Nusa Tenggara Barat dengan ibukota Woha. Pulau Sumbawa dibatasi oleh Selat Alas di sebelah barat (memisahkan dengan Pulau
Lombok), Selat Sape di sebelah timur (memisahkan dengan Pulau Komodo), Samudra Hindia di sebelah selatan, serta Laut Flores di sebelah utara. Kabupaten ini mempunyai luas 438.940 ha (BPS Kabupaten Bima, 2016). Kabupaten Bima terletak pada koordinat 08 08' - 08 57’ LS dan. 118 44' - 119 22' BT Lokasi Kabupaten Bima dalam Provinsi Nusa Tenggara Barat disajikan pada Gambar 2. Dengan kondisi geografis demikian, Kabupaten Bima sebelah utara berbatasan dengan Laut Flores, sebelah selatan dengan Samudera Indonesia, sebelah barat dengan Kabupaten Dompu dan sebelah timur dengan Selat Sape. Kabupaten Bima terdiri atas 18 kecamatan, yaitu Monta, Parado, Bolo, Madapangga, Woha, Belo, Palibelo, Wawo, Langgudu, Lambitu, Sape, Lambu, Wera, Ambalawi, Donggo, Soromandi, Sanggar, dan Tambora (BPS Kabupaten Bima, 2016).

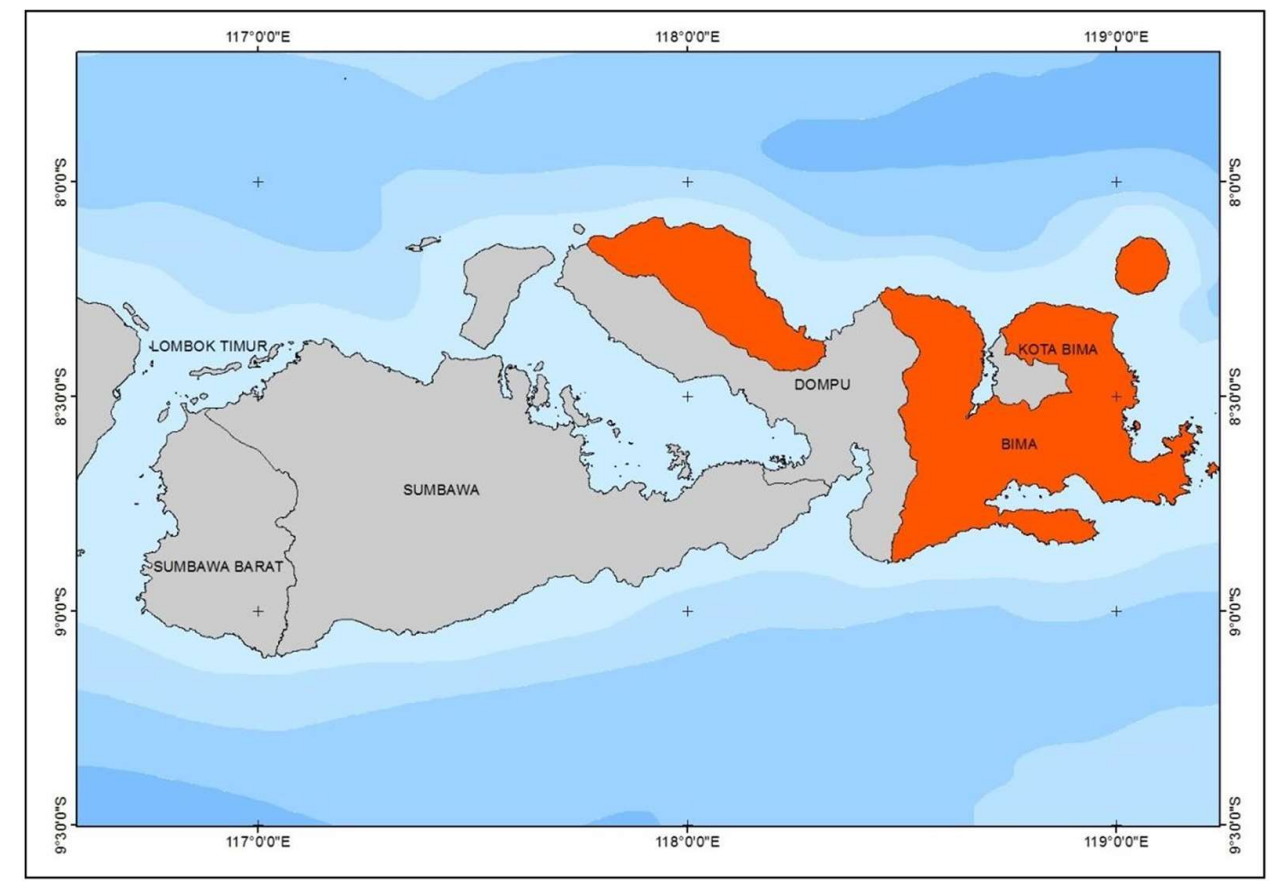

Gambar 2. Peta lokasi Kabupaten Bima, Nusa Tenggara Barat.

Tambora adalah kecamatan terluas di Kabupaten Bima, diikuti Sanggar dan Wera, sementara Belo merupakan kecamatan terkecil atau $1,02 \%$ dari luas kabupaten. Ibukota kabupaten Woha berjarak 25,5 $\mathrm{km}$ dari Kota Bima yang dapat dicapai dengan kendaraan roda dua atau roda empat dengan waktu tempuh \pm 30 menit. Untuk sampai di Kota Bima menggunakan jalur udara melalui Bandara Sultan Muhammad Salahudin yang melayani route dalam negeri. Jalan-jalan berada dalam kondisi baik. Angkutan umum dari dan menuju kabupaten menggunakan taksi travel. Untuk angkutan dalam kabupaten tersedia 


\section{Jurnal Tanah dan Sumberdaya Lahan Vol 7 No 2 : 181-194, 2020 e-ISSN:2549-9793, doi: 10.21776/ub.jts1.2020.007.2.1}

minibus dan oplet/mikrolet dengan trayek hampir ke semua pelosok, sedangkan angkutan antar kecamatan menggunakan ojek sepeda motor.

\section{Baban induk, landform dan relief}

Berdasarkan peta geologi di Pulau Sumbawa skala 1:250.000 lembar Mataram (1807) dan lembar Sumbawa Besar (1907) (Kastowo et al., 1996), serta data/informasi dari pengamatan lapang bahwa Kabupaten Bima terdiri atas beberapa formasi geologi. Secara garis besar formasi batuan terdiri atas bahan endapan permukaan/aluvium, batuan vulkan dan batuan terobosan (vulkan, beku dalam) sebagai landform vulkan tua, telah mengalami perubahan karena erosi ataupun telah mengalami patahan/lipatan. Endapan aluvium terdiri atas endapan liat, dan pasir. Formasi batuan sedimen sebagian besar berupa batuan pasir tufaan, batulempung tufaan, breksi andesit-basalt, yang terombak dan tersedimentasi bersama/sebagai batuan sedimen. Formasi endapan laut dalam terdiri atas batu lanau, napal, serpih, batugamping, batupasir gampingan. Formasi lainnya adalah endapan batugamping koral, endapan kasar kerikil-kerakal dan endapan aluvium pasirlumpur.

Berdasarkan kelompok litologi, bahan pembentuk tanah di Kabupaten Bima dapat dibedakan menjadi bahan endapan permukaan, batuan sedimen, dan batuan gunungapi. Bahan endapan ini merupakan bahan yang termuda berumur Kuarter berasal dari endapan sungai dan sedikit endapan laut. Bahan endapan sungai terdiri atas kerakal, kerikil, pasir lumpur dan liat. Bahan ini menyebar di sepanjang jalur sungai, atau sepanjang pantai. Bahan endapan aluivim sesampainya di muara sungai dipengaruhi kembali oleh aktivitas air laut, yang kemudian membentuk landform marin dan fluviomarin. Batuan gunungapi (vulkan), merupakan batuan beku luar, atau bahan berupa lava bersusunan andesit-breksi, atau sebagai bahan aliran lahar. Batuan vulkan terbentuk pada jaman Tersier dan Kuarter. Sebagian besar batuan/bahan vulkan berupa breksi (andesite basalt), basalt, dan sedikit diorit.

Berdasarkan Peta Tanah Semidetail Kabupaten Bima skala 1:50.000 (BBSDLP, 2016), Kabupaten Bima dibedakan atas 7 grup landform, yaitu: Aluvial (A), Marin (M), Fluvio Marin (B), Karst (K), Tektonik (T), Vulkanik (V) dan Aneka (X). Berdasarkan pengamatan lapangan, landform di daerah yang ditanami bawang merah terdapat grup Aluvial dan vulkanik.

Grup Aluvial (A). Landform ini tergolong muda (resen dan subresen) yang terbentuk akibat proses fluvial (aktivitas sungai), koluvial (gravitasi) atau gabungan kedua proses tersebut. Grup Aluvial yang dijumpai di Kabupaten Bima adalah jalur meander, dataran aluvial, jalur aliran, lahan aluvio dan koluvial, serta dataran antar perbukitan.

Grup Marin (M). Grup Marin merupakan landform yang terbentuk akibat aktivitas air laut (gelombang dan arus), baik proses yang bersifat konstruktif (pengendapan) maupun destruktif (abrasi). Grup Marin yang dijumpai adalah pesisir pasir dan dataran pasang surut lumpur.

Grup Fluvio-Marin (B). Grup FluvioMarin merupakan landform yang terbentuk oleh proses fluviatil dan marin. Keberadaan landform ini dapat terbentuk pada lingkungan laut (berupa delta ataupun dimuara sungai yang terpengaruh langsung oleh aktivitas laut. Grup Fluvio Marin yang dijumpai adalah dataran estuarin dan dataran fluvio-marin.

Grup Karst (K). Landform ini terbentuk akibat proses pelarutan dari bahan penyusun (batugamping, batukapur) dicirikan oleh sungaisungai bawah tanah, gua-gua dengan stalaktit, stalagmit, sinkhole, doline, polje, dan lain-lain. Grup Karst yang dijumpai di Kabupaten Bima adalah dataran, perbukitan, dan pegunungan karst, lereng curam sampai sangat curam. Landform ini terdapat di bagian utara Kabupaten Bima.

Grup Tektonik (T). Landform tektonik merupakan landform yang terbentuk akibat proses tektonik, berupa angkatan, lipatan, dan patahan. Grup Tektonik yang dijumpai di Kabupaten Bima adalah dataran dan perbukitan tektonik yang terbentuk dari formasi sedimen tersier atau yang lebih tua dengan luas 24.899 ha atau $5,92 \%$ dari luas total kabupaten.

Grup Vulkanik (V). Landform vulkanik adalah landform yang terbentuk akibat aktivitas vulkan/gunung berapi. Grup landform vulkanik merupakan landform terluas di Kabupaten Bima, yang menempati wilayah mulai dari barat sampai ke timur. 


\section{Jurnal Tanah dan Sumberdaya Lahan Vol 7 No 2 : 181-194, 2020 e-ISSN:2549-9793, doi: 10.21776/ub.jts1.2020.007.2.1}

\section{Keadaan tanah}

Berdasarkan Peta Tanah Semidetail Kabupaten Bima skala 1:50.000 skala 1:50.000 versi Update (BBSDLP, 2016) bahwa tanah-tanah yang dijumpai di Kabupaten Bima menurut Klasifikasi Tanah Nasional (Subardja et al., 2016) terdiri atas 9 jenis, yaitu Litosol, Aluvial, Regosol, Grumusol, Andosol, Molisol, Kambisol, Gleisol dan Mediteran. Jenis tanah yang terdapat di lokasi pertanaman bawang merah terdiri atas tanah Gleisol, Kambisol, Grumusol, Andosol, dan Mediteran.

Aluvial adalah tanah-tanah yang belum berkembang, dicirikan oleh susunan horizon AC. Pada tingkat macam, Aluvial yang dijumpai adalah Aluvial Gleik dan Aluvial Eutrik. Tanah Aluvial Gleik menurut Keys to Soil Taxonomy (Soil Survey Staff, 2014) diklasifikasikan sebagai Aquic Ustifluvents, Sodic Hydraquents, dan Typic Fluvaquents. Tanah Aluvial Eutrik diklasifikasikan sebagai Typic Ustifluvents. Kedua tanah tersebut berkembang dari endapan liat dan endapan lumpur pada jalur aliran, dataran pasang surut lumpur, dataran estuarin, dan dataran fluvio marin. Sifat-sifat tanah Aluvial yang dijumpai mempunyai penampang dalam, drainase agak terhambat sampai baik, tekstur agak halus sampai sedang, reaksi tanah agak alkalis, kapasitas tukar kation (KTK) sedang, dan kejenuhan basa (KB) tinggi sampai sangat tinggi.

Grumusol adalah tanah-tanah yang belum berkembang, dicirikan oleh susunan horizon AC. Pada tingkat macam, Grumusol yang dijumpai adalah Grumusol Kromik. Tanah Grumusol Kromik menurut Keys to Soil Taxonomy (Soil Survey Staff, 2014) diklasifikasikan sebagai Typic Haplusterts. Tanah Grumusol yang dijumpai terbentuk dari endapan liat pada dataran aluvial dan lahan aluvial dan koluvial. Sifat-sifatnya adalah penampang tanah dalam sampai sangat dalam, drainase baik sampai agak baik dan tekstur halus. Reaksi tanah netral, kapasitas tukar kation (KTK) tinggi, dan kejenuhan basa (KB) sangat tinggi.

Andosol termasuk tanah yang sudah berkembang, dicirikan oleh susunan horison ABw-C. Di kabupaten Bima, tanah Andosol yang dijumpai pada tingkat macam diklasifikasikan sebagai Andosol Eutrik. Tanah ini terbentuk dari abu vulkanik andesit dan andesit basalt pada lereng vulkanik atas. Sifatsifat tanah Andosol yang dijumpai adalah penampang tanah dalam, drainase baik dan tekstur agak halus. Reaksi tanah netral, kapasitas tukar kation (KTK) sedang sampai tinggi, dan kejenuhan basa $(\mathrm{KB})$ sangat tinggi.

Molisol adalah tanah-tanah yang sudah berkembang, ditunjukkan horizon penciri A molik dan $\mathrm{KB} \geq 50 \%$ di seluruh penampang. Tanah Molisol yang dijumpai pada tingkat macam diklasifikasikan sebagai Molisol Vertik, Molisol Litik, dan Molisol Haplik. Tanah berkembang dari endapan liat pada dataran aluvial. Sifat-sifat ketiga tanah Molisol yang dijumpai mempunyai penampang dalam, drainase agak baik, dan tekstur halus. Reaksi tanah netral, kapasitas tukar kation (KTK) tinggi dan kejenuhan basa (KB) sangat tinggi.

Kambisol adalah tanah-tanah yang sudah berkembang, ditunjukkan oleh susunan horison A-Bw-C pada lahan berdrainase baik, dan susunan horison $\mathrm{A}-\mathrm{Bg}-\mathrm{C}$ pada tanah berdrainase terhambat. Tanah Kambisol yang dijumpai pada tingkat macam diklasifikasikan sebagai Kambisol Gleik, Kambisol Litik dan Kambisol Eutrik. Tanah berkembang dari endapan liat pada jalur meander. Sifat-sifat ketiga tanah Kambisol yang dijumpai mempunyai penampang dangkal sampai sangat dalam, drainase agak baik, dan tekstur sedang. Reaksi tanah agak masam, kapasitas tukar kation (KTK) sedang dan kejenuhan basa (KB) sangat tinggi.

Gleisol adalah tanah-tanah yang sudah berkembang, dicirikan oleh susunan horizon A$\mathrm{Bg}-\mathrm{C}$, mempunyai horison bawah permukaan kambik dengan ciri hidromorfik sampai kedalaman $50 \mathrm{~cm}$. Pada tingkat macam, Gleisol di Kabupaten Bima menurunkan Gleisol Eutrik. Tanah ini berkembang dari endapan liat dan pasir pada jalur meander, dataran aluvial, dataran antar perbukitan; endapan lumpur pada dataran pasang surut lumpur, dan dataran estuarin. Sifat-sifat tanah Gleisol yang dijumpai memiliki penampang dalam sampai sangat dalam, drainase terhambat, tekstur halus. Reaksi tanah agak masam sampai agak alkalis, kapasitas tukar kation (KTK) rendah sampai sedang dan kejenuhan basa (KB) sangat tinggi.

Tanah Mediteran termasuk tanah-tanah yang sudah berkembang lanjut ditunjukkan oleh 


\section{Jurnal Tanah dan Sumberdaya Lahan Vol 7 No 2 : 181-194, 2020 \\ e-ISSN:2549-9793, doi: 10.21776/ub.jts1.2020.007.2.1}

susunan horison A-Bt-C, dan struktur yang mempunyai tingkat perkembangan cukup kuat di horison B (argilik) dan memiliki kejenuhan basa (KB) lebih tinggi (> 35\%). Tanah Mediteran yang dijumpai pada tingkat macam menurunkan Mediteran Haplik. Tanah ini berkembang dari batupasir tufaan pada dataran tektonik; dan andesit basalt pada lereng vulkanik tengah dan bawah. Tanah Mediteran mempunyai penampang dalam sampai sangat dalam, drainase baik, tekstur halus sampai agak halus. Reaksi tanah netral sampai agak alkalis, kapasitas tukar kation (KTK) sedang, dan kejenuhan basa $(\mathrm{KB})$ sangat tinggi.

\section{Potensi sumberdaya lahan}

Penyusunan peta kawasan pengembangan cabai dan bawang merah berdasarkan kesesuaian lahan kedua komoditas tersebut. Lahan-lahan yang diarahkan untuk pengembangan kawasan cabai dan bawang merah dan potensi perluasannya adalah lahanlahan yang tergolong sangat sesuai (S1), cukup sesuai (S2), dan sesuai marjinal (S3) jika faktor pembatasnya relatif mudah diatasi dengan tingkat kemampuan masyarakat. Hasil penilaian kesesuaian lahan untuk cabai dan bawang merah disajikan pada Tabel 4.

\section{Karakteristik sumberdaya iklim dan air}

Wilayah Kabupaten Bima beriklim tropis dengan rata-rata bulan kering $(<60 \mathrm{~mm}) 78$ bulan dengan bulan basah kurang dari 3 bulan (> $100 \mathrm{~mm}$ ). Curah hujan tahunan ratarata selama 20 tahun sebesar $1.025 \mathrm{~mm}$ dengan ratarata bulanan 85,4 mm. Sehingga Kabupaten Bima adalah daerah berkategori kering hampir sepanjang tahun, hal ini yang berdampak pada rendahnya potensi ketersediaan air dan sebagian besar sungai kering.

Tabel 4. Kesesuaian lahan tanaman cabai dan bawang merah di Kabupaten Bima, NTB.

\begin{tabular}{|c|c|c|c|c|c|c|c|c|c|}
\hline \multirow[t]{2}{*}{ No } & \multirow[t]{2}{*}{ Kecamatan } & \multicolumn{4}{|c|}{ Cabai (ha) } & \multicolumn{4}{|c|}{ Bawang Merah (ha) } \\
\hline & & S2 & S3 & $\mathbf{N}$ & Total & S2 & S3 & $\mathbf{N}$ & Total \\
\hline 1 & Ambalawi & & 16.021 & 1.279 & 17.299 & & 16.021 & 1.279 & 17.299 \\
\hline 2 & Belo & 33 & 1.954 & 3.995 & 5.982 & 33 & 1.954 & 3.995 & 5.982 \\
\hline 3 & Bolo & 2.172 & 3.016 & 2.222 & 7.410 & 2.172 & 3.016 & 2.222 & 7.410 \\
\hline 4 & Donggo & 277 & 7 & 10.552 & 10.835 & 277 & 7 & 10.552 & 10.835 \\
\hline 5 & Lambitu & & 173 & 5.454 & 5.627 & & 173 & 5.454 & 5.627 \\
\hline 6 & Lambu & & 11.113 & 29.456 & 40.570 & & 11.113 & 29.456 & 40.570 \\
\hline 7 & Langgudu & & 7.199 & 24.161 & 31.360 & & 7.199 & 24.161 & 31.360 \\
\hline 8 & Mada Pangga & 1.789 & 5.165 & 18.388 & 25.342 & 1.789 & 5.165 & 18.388 & 25.342 \\
\hline 9 & Monta & & 6.119 & 13.231 & 19.350 & & 6.119 & 13.231 & 19.350 \\
\hline 10 & Palibelo & 80 & 2.281 & 3.691 & 6.053 & 80 & 2.281 & 3.691 & 6.053 \\
\hline 11 & Parado & & 3.731 & 18.580 & 22.311 & & 3.731 & 18.580 & 22.311 \\
\hline 12 & Sanggar & & 14.006 & 22.432 & 36.438 & & 14.006 & 22.432 & 36.438 \\
\hline 13 & Sape & & 12.843 & 8.419 & 21.262 & & 12.843 & 8.419 & 21.262 \\
\hline 14 & Soromandi & 2.571 & 14.583 & 15.563 & 32.717 & 2.571 & 14.583 & 15.563 & 32.717 \\
\hline 15 & Tambora & 28 & 15.993 & 46.398 & 62.418 & & 11.686 & 50.732 & 62.418 \\
\hline 16 & Wawo & & 6.809 & 8.559 & 15.430 & 62 & 6.809 & 8.559 & 15.430 \\
\hline 17 & Wera & & 23.000 & 23.493 & 46.493 & & 17.938 & 28.554 & 46.493 \\
\hline 18 & Woha & 62 & 5.364 & 6.672 & 12.036 & & 5.364 & 6.672 & 12.036 \\
\hline & Total & 7.011 & 149.375 & 262.546 & 418.932 & 6.984 & 140.007 & 271.942 & 418.932 \\
\hline
\end{tabular}

Curah hujan tertinggi pada bulan Januari tercatat $238 \mathrm{~mm}$ dengan hari hujan selama 15 hari. Musim kemarau terjadi pada bulan MaretOktober di mana jumlah curah hujan dalam satu dasarian (10 hari) kurang dari 50 milimeter dan diikuti oleh beberapa dasarian berikutnya. Musim hujan terjadi pada November-Februari dimana jumlah curah hujan dalam satu dasarian
(10 hari) sama atau lebih dari 50 milimeter dan diikuti oleh beberapa dasarian berikutnya (Gambar 3). Curah hujan di Kabupaten Bima dari tahun 1994 hingga tahun 2014 berfluktuasi. Curah hujan tertinggi selama kurun waktu 20 tahun tersebut terjadi pada tahun 2010 yaitu $1452 \mathrm{~mm}$. Secara rinci tren curah hujan di Kabupaten Bima selama 20 tahun disajikan 


\section{Jurnal Tanah dan Sumberdaya Lahan Vol 7 No 2 : 181-194, 2020 e-ISSN:2549-9793, doi: 10.21776/ub.jts1.2020.007.2.1}

pada Gambar 4. Menurut tipe iklim Schmidt Ferguson, wilayah di bagian timur Kabupaten Bima pada ZOM 240 yang meliputi kecamatan Rasanae, Wawo, Sape, Belo, Wera, Lambu, Palibelo, dan Woha tergolong tipe iklim F dengan kurang dari 3 bulan basah dan lebih dari 6 bulan kering. Suhu udara rata-rata berkisar

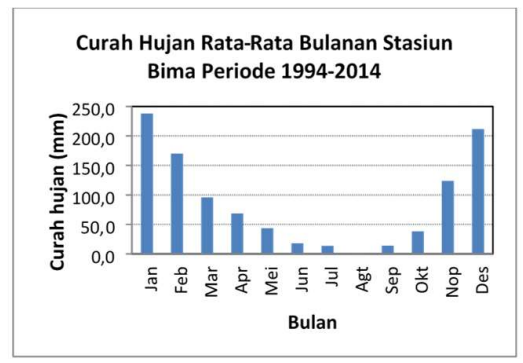

Gambar 3. Fluktuasi curah hujan rata-rata bulanan stasiun meteorologi Bima periode 1994 2014.

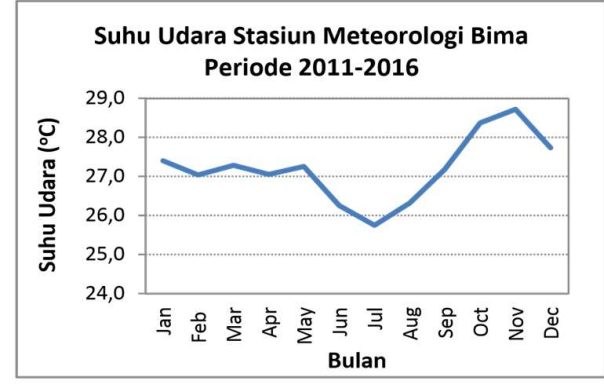

Gambar 5. Fluktuasi suhu udara rata-rata bulanan stasiun meteorologi Bima periode 20112016.

Kabupaten Bima memiliki drainase yang tergenang dan tidak tergenang. Pengaruh pasang surut hanya seluas 1.085 ha atau $0,02 \%$ dengan lokasi terbesar di wilayah pesisir pantai. Luas lokasi yang tergenang terus menerus adalah seluas 194 ha, yaitu wilayah Dam Roka, Dam Sumi dan Dam Pelaparado, sedangkan wilayah yang tidak pernah tergenang di Kabupaten Bima adalah seluas 457.989 ha. Kawasan bawang merah di Kabupaten Bima pada umumnya ditanam di lahan sawah terdapat di Kecamatan Sape, Lambu, Belo, Monta, Woha, dan Wera, sedangkan potensi di Kecamatan Ambalawi dan Soromandi. Di Kecamatan Lambu dan Sape bawang merah ditanam 2-3 kali tiap tahun. Sumber air yang digunakan sebagian air antara $25,8-28,7^{\circ} \mathrm{C}$. Suhu udara terendah terjadi pada bulan Juli, sedangkan suhu udara tertinggi tejadi pada bulan Nopember (Gambar 5). Kelembaban rata-rata berkisar antara 72,8$85,4^{\circ} \mathrm{C}$. Kelembaban terendah terjadi pada bulan Oktober, sedangkan kelembaban udara tertinggi tejadi pada bulan Februari (Gambar 6).

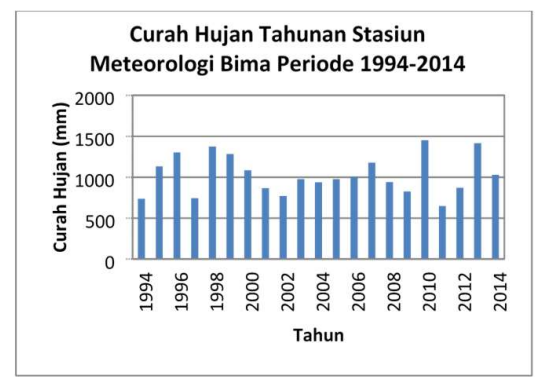

Gambar 4. Fluktuasi curah hujan tahunan stasiun meteorologi Bima periode 1994-

2014.

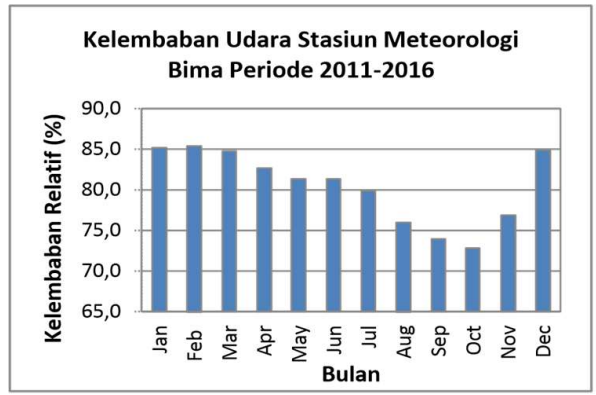

Gambar 6. Fluktuasi kelembaban relatif ratarata stasiun meteorologi Bima periode 2011-

2016.

permukaan (curah hujan dan saluran irigasi), sebagian dari sumur dangkal 2-4 m dan sebagian lainnya dari sumur bor 15-20 m. Air dari saluran irigasi dipompa dengan pompa sentrifugal 4,55,5 pk kemudian dialirkan melalui saluran terbuka langsung ke lahan, sebagian kecil petani mencoba untuk menggunakan teknik irigasi impact sprinkler (Gambar 7). Air dari sumur dangkal dialirkan ke bak tampung mini, kemudian disiramkan ke lahan bawang merah menggunakan alat penyiram tradisional yang dinamakan "boru" (Gambar 8). Air dari sumur bor diusahakan secara perorangan dengan ratarata per petak ukuran 2000-2500 $\mathrm{m}^{2}$ terdapat 1 sumur bor sehingga dalam 1 hektar lahan terdapat 4-6 sumur bor. 


\section{Jurnal Tanah dan Sumberdaya Lahan Vol 7 No 2 : 181-194, 2020 \\ e-ISSN:2549-9793, doi: 10.21776/ub.jts1.2020.007.2.1}

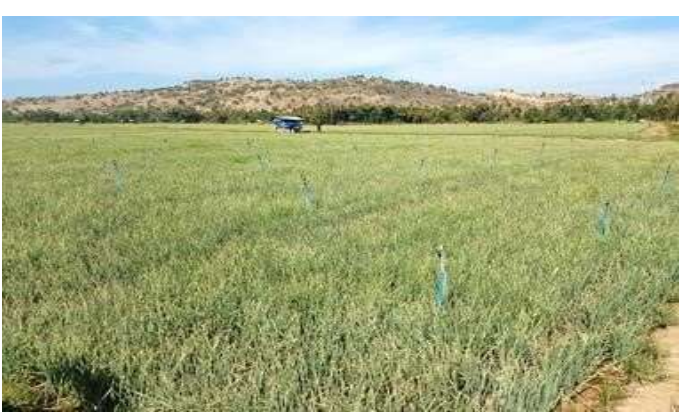

Gambar 7. Teknik irigasi impact sprinkler.

Air dari sumur bor dipompa menggunakan pompa sentrifugal $4,5-8,5 \mathrm{pk}$ kemudian didistribusikan lewat pipa PVC 1,5-2 inchi langsung ke lahan menggunakan pipa tersebut yang dilubangi (drip pipe). Di Kecamatan Monta sumber airnya dari "DAM Pelaparado" yang dipompa menggunakan pompa sentrifugal/ jetpump 4,5-5,5 pk kemudian dialirkan ke lahan menggunakan selang plastik. Di Kecamatan Woha pada musim hujan $(\mathrm{MH})$ dan musim kering kesatu (MK-1) memanfaatkan air hujan, sedangkan pada MK-2 irigasi menggunakan sumur bor yang dipompa dengan pompa sentrifugal 5,5 pk kemudian distribusi ke lahan menggunakan selang plastik. Kecamatan Wera pengembangan bawang merah terdapat di Desa Nunggi, sumber air dari sumur bor yang dipompa dengan menggunakan pompa sentrifugal 4,5-8,5 pk, kemudian didistribusikan ke lahan melalui pipa tertutup 1,5-2 inchi. Potensi bawang merah di Kecamatan Ambalawi banyak terdapat tanaman bawang merah di Desa Nipa, sumber air pada MH dan MK-1 dari curah hujan, sedangkan pada MK-2 dari DAM Lapanggo yang dialirkan melalui saluran terbuka di sekeliling lahan, kemudian teknik penyiraman menggunakan boru. Potensi lainnya terdapat di Kecamatan Soromandi pada MH dan MK-1 sumber air dari curah hujan.

\section{Kawasan hortikultura cabai dan bawang merah}

Untuk tanaman cabai di Kabupaten Bima tidak dapat dibuat sebagai kawasan pengembangan karena lahan eksisting tanaman cabai terpencar-pencar dalam luasan sempit. Namun demikian, potensi untuk pengembangan ekstensifikasi tanaman cabai di daerah ini masih cukup luas seperti disajikan pada Gambar 9 dan Tabel 5. Potensi pengembangan cabai di daeah

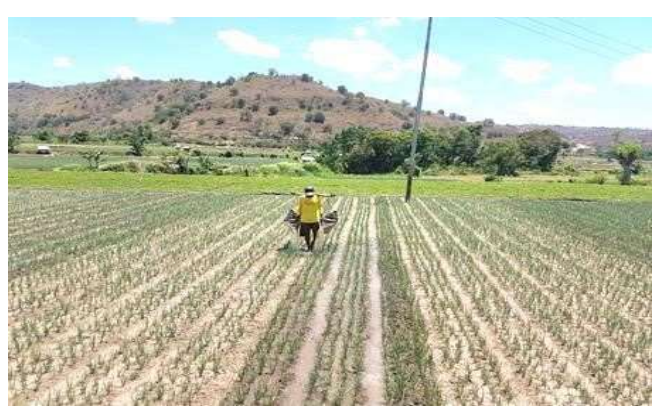

Gambar 8. Teknik irigasi tradisional "Boru”.

ini dibedakan atas 2 kelas, yaitu potensi pengembangan tinggi (P.1) seluas 3.280 ha, dan potensi pengembangan sedang (P.2) seluas 42.879 ha. P.1 tersebar di Kecamatan Belo, Bolo, Donggo, Mada Pangga, Palibelo, Soromandi, Tambora dan Woha. Lahan-lahan di daerah tersebut memiliki kesesuaian lahan cukup sesuai dengan faktor pembatas dominan curah hujan rendah serta unsur hara nitrogen dan fosfor rendah. P.2 tersebar di seluruh kecamatan yang ada di Kabupaten Bima. Namun luasan lahan tertinggi berturut-turut dari yang paling luas berada di Kecamatan Wera, Ambalawi, Tambora, Soromandi, Sanggar, Sape, dan Lambu, memiliki kesesuaian lahan tergolong sesuai marjinal dengan faktor pembatas dominan berupa curah hujan rendah. Pengaturan pola dan waktu tanam serta pemanfaatan sumber-sumber air permukaan (sungai) atau air tanah dangkal dapat meningkatkan potensi dan kesesuaiannya.

Kawasan pengembangan bawang merah di Kabupaten Bima disajikan pada Tabel 6 dan Gambar 10. Di daerah ini kawasan pengembangan bawang merah seluas total 8.696 ha, terdiri atas 2 kelas berdasarkan selisih antara produktivitas yang dicapai saat ini dengan potensi produktivitas bawang merah. Lahan kawasan pengembangan BA.2 berada di Kecamatan Belo, Woha, dan Monta dengan luas 5.894 ha. Produktivitas bawang merah di kecamatan tersebut mencapai sekitar 12-15 t ha ${ }^{-1}$, sehingga peningkatan produktivitasnya sedang. Kesesuaian lahan pada BA.2 adalah cukup sesuai (S2) dan sesuai marjinal. Pada lahan cukup sesuai seluruh faktor pembatasnya adalah drainase agak baik, tekstur halus, dan kemiringan lereng 3-8\%. Pada sesuai marjinal faktor penghambat yang paling dominan adalah drainase terhambat. 


\section{Jurnal Tanah dan Sumberdaya Lahan Vol 7 No 2 : 181-194, 2020 \\ e-ISSN:2549-9793, doi: 10.21776/ub.jts1.2020.007.2.1}

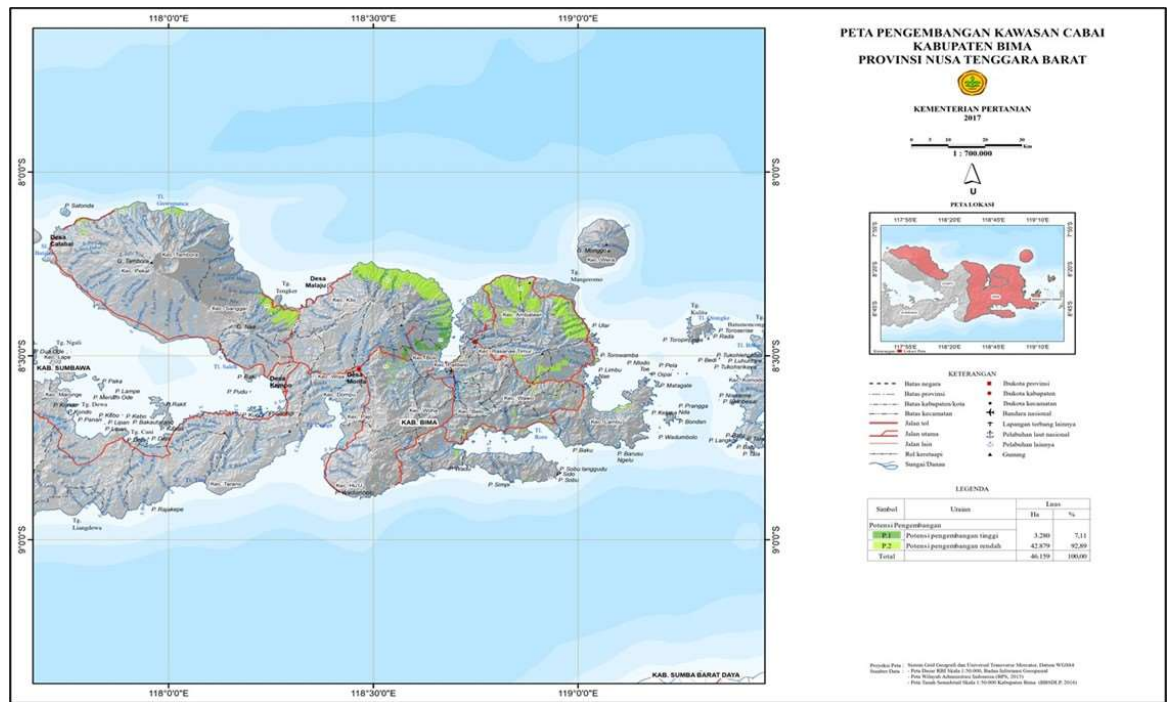

Gambar 9. Peta pengembangan kawasan cabai, Kabupaten Bima, Provinsi Nusa Tenggara Barat.

Tabel 5. Legenda peta pengembangan kawasan cabai di Kabupaten Bima, NTB.

\begin{tabular}{llrr}
\hline Simbol & Uraian & \multicolumn{2}{c}{ Luas } \\
\cline { 3 - 4 } & & \multicolumn{1}{c}{ ha } \\
\hline & Potensi Pengembangan & & \\
P.1 & Potensi pengembangan tinggi & 3.280 & 7,11 \\
P.2 & Potensi pengembangan rendah & 42.879 & 92,89 \\
\hline \multicolumn{2}{l}{ Total } & $\mathbf{4 6 . 1 5 9}$ & $\mathbf{1 0 0 , 0 0}$ \\
\hline
\end{tabular}

Lahan kawasan pengembangan BA.3 untuk bawang merah berada di Kecamatan Lambu dan Sape dengan luas 2.802 ha. Produktivitas bawang merah di Kecamatan Lambu dan Sape mencapai sekitar 15-18 $\mathrm{t}$ ha ${ }^{-1}$ sehingga peningkatan produkvitasnya rendah. Seluruh lahan pada BA.3 berada pada kesesuaian lahan marjinal (S3) dengan faktor pembatas berupa curah hujan rendah dan drainase terhambat sebagai faktor pembatas dominannya. Curah hujan rendah sudah diatasi petani dengan pemanfaatan air tanah dangkal dan juga air irigasi, sehingga kesesuaian lahannya dapat meningkat menjadi cukup sesuai (S2) atau bahkan sangat sesuai (S1) dengan tambahan perbaikan teknologi. Lahan yang juga ditanami bawang merah namun tidak sebagai kawasan tetapi hanya sebagai eksisting (BA-e) berada di Kecamatan Soromandi dan Ambalawi. Secara eksisting luas lahan untuk bawang merah mencapai 470 ha. Namun lahan di Kecamatan Soromandi dan Ambalawi tersebut tidak bisa dijadikan kawasan karena berada tepat di pinggir pantai, dikhawatirkan akan mudah berubah fungsi lahan. Kesesuaian lahan pada BA-e adalah sesuai marjinal dengan faktor pembatas yang dominan adalah curah hujan rendah dan unsur hara nitrogen sangat rendah. Selain lahan kawasan pengembangan bawang merah, juga terdapat lahan potensial untuk pengembangan ekstensifikasi, yakni seluas 60.363 ha terdiri atas potensi pengembangan tinggi (P.1) seluas 4.675 ha, dan potensi pengembangan sedang (P.2) seluas 55.688 ha. P.1 tersebar di Kecamatan Belo, Bolo, Donggo, Mada Pangga, Palibelo, Soromandi dan Wawo, dengan kesesuaian lahan termasuk cukup sesuai dengan faktor penghambat dominan unsur hara nitrogen dan fosfor rendah. P.2 tersebar di seluruh kecamatan yang ada di Kabupaten Bima, dengan luasan lahan tertinggi berturut-turut dari yang paling luas berada di Kecamatan Wera, Ambalawi, Soromandi, Sanggar, Sape, Tambora, dan Lambu. Kesesuaian lahan P.2 adalah sesuai marjinal dengan faktor pembatas dominan curah hujan rendah. 


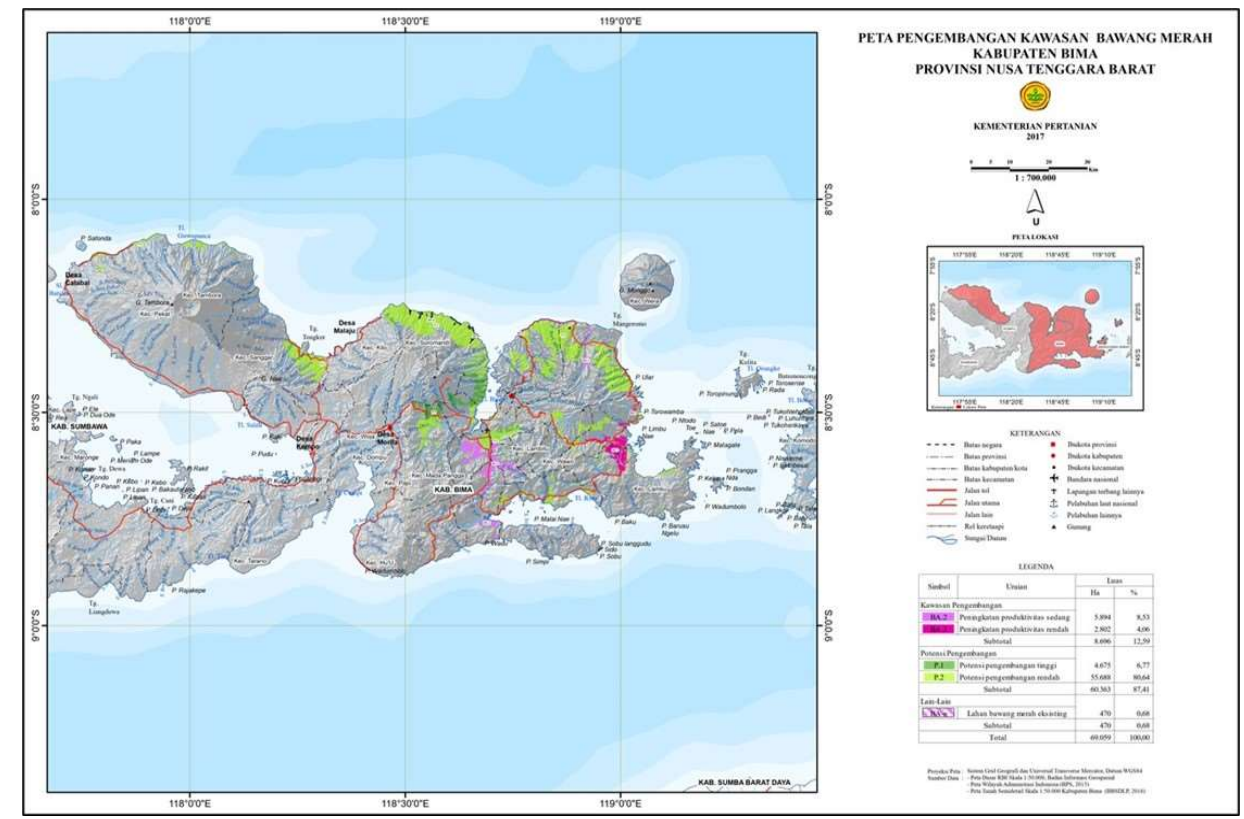

Gambar 10. Peta pengembangan kawasan bawang merah, Kabupaten Bima, Provinsi Nusa Tenggara Barat.

Tabel 6. Legenda peta pengembangan kawasan bawang merah di Kabupaten Bima, Nusa Tenggara Barat.

\begin{tabular}{clcc}
\hline Simbol & Uraian & \multicolumn{2}{c}{ Luas } \\
\cline { 3 - 4 } & & ha & \% \\
\hline \multirow{2}{*}{ BA.2 } & Kawasan Pengembangan & & \\
BA.3 & Peningkatan produktivitas sedang & 5.894 & 8,48 \\
& Peningkatan produktivitas rendah & 2.802 & 4,03 \\
\cline { 2 - 4 } & Subtotal & $\mathbf{8 . 6 9 6}$ & $\mathbf{1 2 , 5 1}$ \\
\hline \multirow{2}{*}{ P.1 } & Potensi Pengembangan & & \\
P.2 & Potensi pengembangan tinggi & 4.675 & 6,72 \\
& Potensi pengembangan sedang & 55.688 & 80,09 \\
\cline { 2 - 4 } & Subtotal & $\mathbf{6 0 . 3 6 3}$ & $\mathbf{8 6 , 8 2}$ \\
\hline \multirow{2}{*}{ BA-e } & Lain-Lain & & \\
& Lahan bawang merah eksisting & 470 & 0,68 \\
\cline { 2 - 4 } & Subtotal & $\mathbf{4 7 0}$ & $\mathbf{0 , 6 8}$ \\
\cline { 2 - 4 } & Total & $\mathbf{6 9 . 5 2 9}$ & $\mathbf{1 0 0 , 0 0}$ \\
\hline
\end{tabular}

\section{Kesimpulan}

Kabupaten Bima mempunyai kawasan bawang merah seluas 8.696 ha dan potensi pengembangan ekstensifikasi seluas 60.363 ha. Untuk tanaman cabai Kabupaten Bima tidak memiliki kawasan namun mempunyai potensi pengembangan ekstensifikasi seluas 46.159 ha. Rekomendasi pengelolaan lahan dan air: a) Perlu digulud untuk menjaga kelembaban, $\mathrm{pH}$, suhu, dan kecukupan air tanah; supaya akar tanaman lebih kokoh; untuk mempermudah dalam irigasi, mencegah tanaman dari serangan hama dan penyakit; supaya tanaman tumbuh tertib, teratur sesuai garis alur bedengan, dan mempermudah petani dalam monitoring 


\section{Jurnal Tanah dan Sumberdaya Lahan Vol 7 No 2 : 181-194, 2020 e-ISSN:2549-9793, doi: 10.21776/ub.jts1.2020.007.2.1}

tanaman (perawatan, penyiangan, penyiraman, dan pemanenan)

b) Perlu persiapan tanam yang matang terutama untuk tanam pada MK-2 supaya tidak terlambat tanam karena pada akhir MK-2 air sangat terbatas dengan memberikan pendampingan kepada petani dengan teknologi penentuan waktu tanam

c) Kelembaban relatif tinggi pada bulan Desember-Juni maka saat tanam pada bulan-bulan tersebut diperlukan pemasangan perangkap hama hayati untuk antisipasi serangan OPT (feromon exi, light trap, perangkap likat kuning/putih/biru, pestisida organic, border pertanaman (benih jagung)

d) Karena air sangat terbatas untuk tanam pada MK-2 diperlukan irigasi suplementer dari embung, dam parit, atau air tanah (teknologi panen air).

e) Perlu teknik irigasi yang efisien dengan implementasi impact sprinkler dengan tujuan untuk membersihkan spora pada daun dan menyemprotkan air pada individu tanaman sesuai dosis yang direkomendasikan.

f) Perlu pengembangan sistem irigasi pompa tenaga surya untuk irigasi agar memanfaatkan tenaga surya untuk menggerakkan pompa tanpa penggunaan BBM sehingga hemat energi dan ramah lingkungan (mengurangi emisi $\mathrm{CO}_{2}$ )

g) Perlu distribusi air dengan saluran tertutup (pipanisasi) untuk mengurangi penguapan sehingga pemenfaatan air lebih optimal.

\section{Daftar Pustaka}

Bakosurtanal. 2017: http:// www.bakosurtanal. go.id/ bakosurtanal/peta-rbi/.

BBSDLP. 2016. Atlas Peta Tanah Semidetail Kabupaten Bima Skala 1:50.000. Balai Besar Penelitian dan Pengembangan Sumberdaya Lahan Pertanian, Badan Penelitian dan Pengembangan Pertanian. Kementerian Pertanian.

BPN (Badan Pertanahan Nasional). 2012. Peta Penggunaan Lahan Indonesia. BPN, Jakarta http://id.climate-data.org/continent/asia/. Climate-data.org.

BPS Kabupaten Bima. 2016. Kabupaten Bima Dalam Angka. Badan Pusat Statistik.

Djaenudin, D., Marwan, H., Subagjo, H. dan A. Hidayat. 2003. Petunjuk Teknis Evaluasi Lahan untuk Komoditas Pertanian. Balai Penelitian Tanah, Bogor.

FAO. 1976. A Framework for Land Evaluation. Soil Resources Management and Conservation Service Land and Water Development Division. FAO Soil Bulletin No. 32. FAO-UNO, Rome.

Kastowo, Gerhard, W.L., Gafoer, S. dan Amin, T.C. 1996. Peta Geologi Lembar Mataram (1807) dan lembar Sumbawa Besar (1907), Nusa Tenggara, skala 1:250.000. Pusat Penelitian dan Pengembangan Geologi, Bandung.

Kementan. 2013. Peta Sebaran Luas Baku Lahan Sawah Berdasarkan Kesepakatan antara Kementan, BPN, dan BPS. Badan Pertanahan Nasional, Jakarta.

Kementerian ATR. 2015. Peta Penguasaan Lahan. Kementerian Agraria dan Tata Ruang/Badan Pertanahan Nasional. Jakarta.

Kementan. 2017. Atlas Peta Potensi Pengembangan Kawasan Cabai dan Bawang Merah Kabupaten Bima, Provinsi Nusa Tenggara Barat Skala 1:50.000. Sekretariat Jenderal Kementerian Pertanian. ISBN: 978-979-582-178-6. 58 hal.

KLHK. 2013. Peta Status Kawasan Hutan Indonesia. Kementerian Lingkungan Hidup dan Kehutanan. Jakarta.

Oldeman, L.R., Las, I. and Muladi. 1978. An Agroclimatic map of Maluku and Irian Jaya, scale 1:4,500,000. Contribution of Centre for Research Institute for Agriculture No. 60, Bogor. 20p.

Puslitbangtanak. 2003. Atlas Sumberdaya Iklim Pertanian Indonesia skala 1:1.000.000. Pusat Penelitian dan Pengembangan Tanah dan Agroklimat, Badan Penelitian dan Pengembangan Pertanian, Bogor.

Ritung, S., Nugroho, K., Mulyani, A. dan Suryani, E. 2011. Petunjuk Teknis Evaluasi Lahan untuk Komoditas Pertanian. Edisi Revisi 2011. Balai Besar Penelitian dan Pengembangan Sumberdaya Lahan Pertanian. Bogor. $166 \mathrm{hlm}$.

Schmidt, F.H. and Ferguson, J.H.A. 1951. Rainfall Types Based on Wet and Dry Period Ratios for Indonesia with Western New Guinea, Verh. No. 42. Kementerian Perhubungan, Jawatan Met. dan Geofisika. Jakarta.

Soil Survey Staff. 2014. Keys to Soil Taxonomy. 12 $2^{\text {nd }}$ ed. USDA Natural Resources Conservation Service. Washington DC.

Subardja, D.S., Ritung, S., Anda, M., Sukarman, Suryani, E. dan Subandiono, R.E. 2016. Petunjuk Teknis Klasifikasi Tanah Nasional. Edisi 2/2016. Bogor: Balai Besar Penelitian dan Pengembangan Sumberdaya Lahan Pertanian (BBSDLP), Badan Penelitian dan Pengembangan Pertanian, Kementerian Pertanian, 53 hal. 